a further example of the practical application of research techniques and a precursor of greater things to come.

Such social research is part of a distinctive tradition of British social science, and $\mathrm{Mr}$. Morrison expects a great extension of the techniques of exact quantitative study on society, social groups and their environment on one hand, and on the other the extension of social research into the qualitative field. In regard to the first, Mr. Morrisen urged the importance of a study of social mobility - the rate and machinery of transfer from one social class or group in one society to another. He suggested that a study in Great Britain might show the universities acting to some extent as engines of social mobility, and to a greater extent as instruments of individual economic advancement. Again, the problem of marriage and the question of actual geographic mobility requires investigation. In spite of their increasing importance in the age structure, we know little about the old as a social factor beyond their numbers. We know little about the factors that shape the choice of occupation on leaving school, and how far this is affected by the occupation of their parents. Besides this quantitative approach, we need as supplement a development of the case-history method -an intensive study of a number of individuals either by specially worked out methods of question and answer or by methods of word-association and pictureassociation. The development of personality and ability tests in the Services is a small beginning of this kind of approach, but the programme of extended social research would call for the creation of a new generation of social workers, and the training of large groups of students. Mr. Morrison is looking with keen anticipation to the extension in the social field of scientific techniques. Social scientists have a tremendous contribution to make to intelligent enlightened government, and Mr. Morrison believes that the full fruition of the social sciences, at present in a stage corresponding to the early phases of the physical sciences when they were uncertain about their explanations of cause, may not lie so far ahead of us.

\section{PETROLEUM IN WAR AND PEACE}

$\mathrm{T}$ HE American Office of War Information has recently received a publication entitled "Developments and Trends in American Industries (Oil Mining and Refining; High Octane Gasoline)" which is in fact a collation of excerpts from trade magazine articles and other sources. It covers practically every activity of the American petroleum industry to-day, and gives some striking pointers as to the way in which war-time scientific discoveries will be harnessed to meet peace-time requirements.

Driven by the necessity for producing high-quality aviation fuels in enormous quantities, research workers, sponsored by the Petroleum Industry for War Council and the Aviation Gasoline Advisory Committee, have made startling progress. Until recently, 100-octane gasoline was regarded as an optimum fuel; but it has been superseded as a standard. There is a new 'Supergas' called triptane (paraffinic-trimethyl-butane), which is 50 per cent superior to iso-octane from which 100-octane gas is obtained; its anti-knock qualities are such that no commercial engine has been built which is capable of utilizing its full power. There is 'Dynafuel', which is also 50 per cent more powerful than standard 100-octane fuel, and there are no doubt other fuels of similar calibre which will become commercially available in peace-time. One is tempted to forget that the use of 100-octane spirit or super-gasoline for post-war motoring purposes implies the evolution of a 'super-car'. It is, in fact, unlikely that such fuels will be used in motor-cars for some long time to come, but it is interesting to note that petroleum chemists do envisage the production of a 70-mileto-the-gallon motor spirit, not to mention 100,000 mile tyres, and 20,000-mile lubricating oils.

Second only to aviation gasoline in war-time importance is the production of toluene for T.N.T. (trinitrotoluene). During the War of 1914-18, practically all the toluene used was produced from coal tar; but to-day, although more toluene is being manufactured in that way than ever before, the greater part is being supplied from petroleum oil refineries. Indeed, the capacity of hydroformer installations and attendant toluene extraction and purification plants has been so increased that it has been found possible to divert some of the toluene to 100-octane activities, after fulfilment of all requirements for explosives. Toluene in peace-time is a commercial solvent used in dyes and paint manufacture; but quantities required are not in any way proportionate to war-time demands. Petroleum chemists foresee a sharp decline in toluene production after the War, but they equally foresee the possibility of converting toluene-manufacturing plants into machinery for making gasoline-blending agents.

Other war-time activities of the petroleum industry include the supply of a large part of the butadiene for the production of Buna- $S$ type synthetic rubber; production of high-quality lubricating oils, hydraulic oils, and special types of lubricants capable of withstanding the bitter winter conditions of Greenland or alternatively the heat of the Sahara desert. Waxes more moisture-proof than tin, rust preventives, deicing materials, fireproofing compositions for soldiers' tents, preservatives for mosquito nets, medicines, anæsthetics and a host of other war-time commodities are prepared from petroleum derivatives. In fact, refining has become so highly skilled compared with the old days when cuts were made to satisfy demand for one product only that its repercussions on postwar industry will be nothing short of revolutionary. To-day the petroleum chemist is master of a formid. able number of highly specialized processes; for example, hydrogenation, dehydrogenation, hydroforming, reforming, alkylation, polymerization, isomerization, catalytic cracking, aromatization, eyclization, etc., and he literally tears apart (cracks) the petroleum molecule and reassembles it into the pattern he desires.

But it is not only the petroleum chemist who has forged ahead. Other branches of the industry have made parallel advances. In 1922 the deepest producing well in the world was in the Orange Field, Texas; it reached a depth of $5,490 \mathrm{ft}$. To-day a well in the Terrebone Parish Field of Louisiana has been drilled to, and is producing at, a depth of $13,475-90 \mathrm{ft}$. A new era in the art of exploration and discovery began with the use of the torsion balance and the seismograph. To-day gravimetric methods, electrical measurements, aerial mapping, geochemical and radiation techniques are all available to assist in the search for oil. Before the entry of the United States into the War, practically all the petroleum and petroleum products consumed in the 
Atlantic Coast States were transported there by tanker. Now the "Big Inch" pipe-line is delivering more than 300,000 barrels of crude oil daily to refineries on the Atlantic seaboard, while the "Little Big Inch" delivers domestic fuel oil to the New York Harbour area. The "Big-Inch" main line is 1,254 miles long and the "Little Big-Inch" 1,475 miles.

\section{SOUTH AFRICAN INSTITUTE FOR MEDICAL RESEARCH}

$\mathrm{T}$ HE annual report for 1943 of the South African Institute for Medical Research, Johannesburg, is a record of valuable war and other work. The work of the South African Medical Corps Establishment is directed from the Institute and is organized into eight sections. Their work includes the supply and administration of the seven large and fifteen small laboratories situated at military hospitals all over the Union and the two mobile laboratories based on the Institute; training of personnel in tropical medicine and laboratory work, which has been extended to naval medical officers; a military blood transfusion service, which has developed considerably; the supply of glucose saline and other fluids for intravenous use; a snake-catching unit, which caught an average of 50-75 cobras and puff-adders a month to provide venom for the manufacture of antivenene by the Institute (a larger and more permanent snake farm at Barberton is being planned and a valuable agreement has been made with the director of the Pasteur Institute, Brazzaville, French Equatorial Africa; for the supply of venoms from equatorial snakes); and a unit for catching gerbils for the use of the typhus-vaccine department, which catches about 1,000 gerbils a month. Assays of vitaminized foodstuffs have been done by the biochemical department for the Director of Supplies, the Red Cross Prisoner-of-War Parcels Section, and other authorities. The Institute is at present the only laboratory in South Africa able to undertake the assay of vitamins in foods. An important part of the war effort has been the continued production of typhus and yellow fever vaccines and other curative and protective sera for military use, and also the building up of a reserve of anti-gas-gangrene serum.

Research work has been done on pneumonia, meningitis, diphtheria, tubereulosis endotoxoid vaccine, tetanus, whooping cough, dysentery, plague, syphilis and other diseases. The enzyme purification and concentration of tetanus and diphtheria antitoxin, anti-gas-gangrene serum and polyvalent antivenene has made such progress that it is possible to plan large-scale manufacture of various antitoxins by this process. The susceptibility of various South African rodents to vole acid-fast mycobacterium of tuberculosis has been studied. Gerbils dying after a dose of $0.0001 \mathrm{mgm}$. had lesions with a histological appearance between those of tuberculosis and leprosy. Much work has been done on anti-typhus vaccines. It is claimed that experiments with the intradermal injection of typhoid vaccine have given satisfactory results; with this method less vaccine is required and there are no local or general reactions.

Considerable research work has been done on gas gangrene, one interesting result of which has been that, among eleven samples of sera of wild animals examined, the sera of two zebras, one inyala, four impala and four kudu contained $C l$. welchii antitoxin.

It has been shown for the first time that epidemic typhus in the Transkei Territory is transmitted by lice. Murine typhus and tick-bite fever also occur in this territory. By serological tests, using pure Rickettsial suspensions, it has been found possible to. differentiate between epidemic typhus, murine typhus and tickbite fever. .

Entomological work has included a study of the distribution of sandflies; species which transmit kala-azar have been found in Southern Rhodesia; this discovery is important because troops returning from areas in which kala-azar is endemic may bring home this disease. A survey of the fleas of the South African Union is also being made. Other subjects of study have been rat-mite dermatitis, due to Liponyssus bacoti, which is very common on rats in Johannesburg, intestinal myiasis due to Dipterous larvæ, the toxin found in the eggs of ticks which causes tick-paralysis and the fungal and nematode parasites of mosquito larvæ.

The Biochemical Department has done work on human nutrition, the nutrition of mosquito larvæ, carbohydrate metabolism and the mechanism of the sulphonamide methæmoglobinæmias.

The routine work of the Institute has again increased, although the military laboratories have taken over some of this. Further expansion of the Serum Production Department has been necessary. The large-scale serum-drying and freezing plant, the cost of which was borne by Sir Ernest Oppenheimer, has been completed and is in use. Very large quantities of vaccines have been produced. Typhoid endotoxin immunization in the Witwatersrand mines has reduced the annual incidence of typhoid since 1934 from $5 \cdot 26$ to $0 \cdot 25$ per 1,000 and the annual mortality from $1 \cdot 18$ to $0 \cdot 05$ per 1,000 .

The reports of the branch laboratories at Port Elizabeth and Bloemfontein indicate that these also are vigorously developing the work of the parent Institute.

G. Lapage.

\section{AERIAL SYSTEMS FOR SHORT RADIO WAVES}

A

RECENT meeting of the Radio Section of the Institution of Electrical Engineers was devoted to the presentation of two papers dealing with the theory and experimental performance of special aerial array systems for short and ultra-short radio waves.

The first paper was by E. B: Moullin and was entitled "Theory and Performance of Corner Re. flectors for Aerials". For wave-lengths of about one metre, a convenient arrangement comprises a pair of reflecting sheets inclined to one another to form a V, with a single aerial on the bisector. Dr. Moullin shows that the field from such a system can be calculated by image treatment and that an algebraic formula can be found when the angle of the $V$ or corner reflector is a proper fraction of $180^{\circ}$. A numerical example given in the paper illustrates the convenience of the Fourier series for evaluating the radiation pattern when the aerial is sufficiently distant from the apex to make the main beam much sharper than a sinusoid, and concurrently to produce side-lobes. 